\title{
Layanan “SAPA RATU” Strategi Layanan Perpustakaan di Masa Pandemi Covid-19 di Dinas Perpustakaan dan Kearsipan Kota Yogyakarta
}

\author{
Sri Anik Lestari ${ }^{1}$ \\ ${ }^{1}$ Dinas Perpustakaan dan Kearsipan Kota Yogyakarta \\ Jalan Suroto No.9, Kotabaru, Gondokusuman, Yogyakarta \\ HP.: 082325333949; Email: anik.ruby@gmail.com
}

\begin{abstract}
Abstrak
Kasus pandemi-Covid 19 yang meningkat memiliki pengaruh yang besar pada bidang perpustakaan. Oleh karena itu perlu strategi agar perpustakan tetap dapat menjalankan tugas dan fungsinya. Salah satu strategi adalah melaksanakan inovasi layanan perpustakaan. Tujuan penelitian ini adalah mengetahui inovasi layanan "SAPA RATU" di Dinas Perpustakaan dan Kearsipan Kota Yogyakarta. Layanan ini merupakan jenis layanan drive-thru untuk layanan peminjaman dan pengembalian buku. Metode yang digunakan dalam penelitian ini adalah studi kasus dengan pendekatan deskriptif kualitatif. Pengumpulan data melalui pengamatan, dokumentasi, wawancara dan tinjauan literature. Sedangkan teknik analisis data yang digunakan adalah pengumpulan data, reduksi data, penyajian data, pembahasan dan penarikan kesimpulkan. Data yang ada dari fakta yang terjadi pada layanan "SAPA RATU". Pembahasan dalam penelitian ini tentang layanan "SAPA RATU" sesuai dengan 5 (lima) kriteria inovasi layanan publik sesuai Permen PANRB Nomor 7 Tahun 2021 yaitu kebaruan, efektif, bermanfaat, dapat ditiru dan berkelanjutan. Dari kriteria tersebut dapat diketahui kendala terkait efektifitas waktu, pengguna layanan masih rendah, promosi layanan belum maksimal. Sedangkan saran yang diberikan yaitu publikasi yang lebih sering dan sistem yang efektif agar tujuan dari inovasi layanan tersebut dapat mencapai.
\end{abstract}

Kata kunci: strategi layanan perpustakaan; inovasi layanan; drive-thru perpustakaan

\begin{abstract}
Service Innovation "SAPA RATU” Strategy Library Service In The Time Of The Covid-19 Pandemic At The Yogyakarta City Library And Archives Office. The increasing cases of the COVID-19 pandemic have had a significant impact on the library field. Therefore, a strategy is needed so that libraries can still carry out their duties and functions. One method is to implement library service innovations. This study aimed to determine the creation of the "SAPA RATU" service at the Yogyakarta City Library and Archives Office. This service is a type of drive-thru service for borrowing and returning books. The method used in this research is a case study with a qualitative descriptive approach — data collection through observation, documentation, interviews and literature review. While the data analysis techniques used are data collection, data reduction, data presentation, discussion and concluding. Existing data is from the facts that occurred in the "SAPA RATU" service. The discussion in this study is about the "SAPA RATU" service following the 5 (five) criteria for public service innovation according to the PANRB Ministerial Regulation Number 7 of 2021, namely novelty, effective, practical, replicable and sustainable. From these criteria, it can be seen that there are obstacles related to time effectiveness, service users are still low, service promotions have not been maximized. While the suggestions given are more frequent publications and an effective system so that the goals of the service innovation can be achieved.
\end{abstract}

Keywords: library service strategy; service innovation; drive-thru library 


\section{A. Pendahuluan}

Pandemi (Corona Virus Disease of 2019) Covid-19 yang melanda seluruh dunia termasuk di Indonesia semakin tinggi. Covid-19 merupakan penyakit yang disebabkan oleh virus severe acute respiratory syndrome coronavirus 2 (SARS-CoV-2). Gejala yang ditimbulkan gangguan sistem pernapasan, seperti flu, demam, diare, nyeri otot, pusing, mual, sakit tenggorokan, dan infeksi paru-paru (seperti pneumonia). Wabah ini sangat cepat menular melalui percikan ludah (droplet) dan dapat berakibat pada kematian. Untuk mengurangi penularaan Covid-19 cara yang dilakukan adalah memakai masker, mencuci tangan dengan sabun, menjaga jarak, menghindari kerumunan, dan mengurangi mobilitas (interaksi) atau sering disebut (5M). Dengan demikian kebiasaan baru yang diterapkan di masyarakat berdampak pada semua aspek kehidupan baik ekonomi, sosial, pendidikan, budaya, politik dan lain-lain

Saat ini telah memasuki tahun ke-2 (dua) wabah ini menjangkit manusia. Bahkan kasus Covid-19 di Indonesia masuk dalam peringkat ke-3 (tiga) dunia. Indonesia berada di posisi tiga dengan akumulasi kasus mingguan terbesar di dunia. Indonesia mencatat 268.067 kasus positif Covid-19 dalam sepekan (27 Juli-2 Agustus 2021). Jumlahnya turun 5\% dibanding pekan sebelumnya, mencapai 283.000 kasus (20-26 Juli 2021) (Pusparisa, 2021). Sedangkan dalam bentuk grafik dari sumber yang sama tentang perkembangan kasus per tanggal 6 Agustus 2021 dapat dilihat pada Grafik 1.

Pada Grafik 1 tersebut menunjukkan lonjakan kasus yang sangat tinggi dari bulan April 2021-Agustus 2021. Hal itulah menjadi latar belakang penerapan kebijakan Pemberlakuan

Grafik 1: Perkembangan kasus Covid-19 di Indonesia bulan April-Juli 2021. (Sumber: Katadata, 2021)

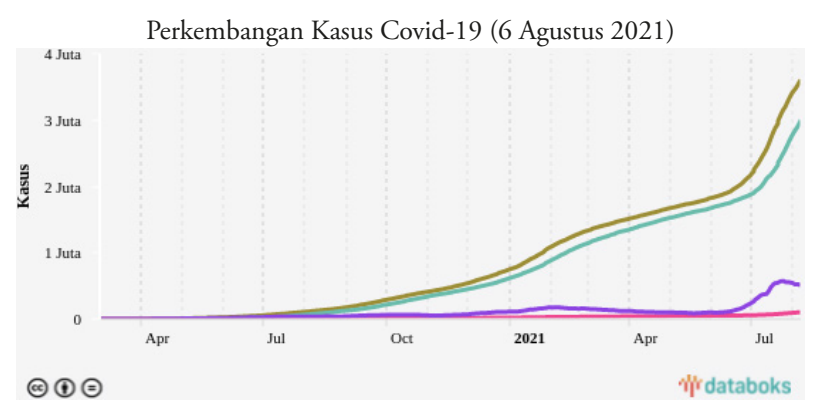

Pembatasan Kegiatan Masyarakat (PPKM) Darurat. Kebijakan tersebut berlaku sejak awal Juli 2021 hingga sekarang. Salah satu aturan dalam kebijakan tersebut adalah 100\% Work from Home (WFH) untuk sektor non-essential diantaranya bidang perpustakaan. Sebelum kebijakan PPKM Darurat, perpustakaan masih dapat membuka layanan secara terbuka. Secara umum, tugas layanan perpustakaan adalah memberikan pelayanan, bimbingan, arahan agar pemustaka dapat memanfaatkan fasilitas perpustakaan dengan maksimal (Samiyati et al., 2021: 34). Akan tetapi layanan tersebut tentu dengan pembatasan pengunjung disertai protokol kesehatan yang ketat. Akan tetapi dalam kebijakan baru saat ini layanan secara langsung tidak dapat dilaksanakan.

Dengan adanya kebijakan tersebut tentu saja perpustakaan harus mencari solusi agar dapat melaksanakan tugas dan fungsinya dengan strategi tertentu. Strategi (Strategic) adalah kiat, cara atau taktik yang dirancang secara sistemik dalam menjalankan fungsi manajamen dalam rangka mencapai tujuan organisasi (Pasalong, 2007). Berdasarkan penjelasan di atas, maka perlunya strategi perpustakaan untuk mencapai tujuanya agar tetap dapat memberikan pelayanan masyarakat dengan cara tertentu melalui mengembangan ide atau gagasan baru.

Dalam upaya peningkatan kinerja penyelenggaraan Pemerintah Daerah, Pemerintah Daerah dapat melaksanakan inovasi. Adapun jenis inovasi pada Pemerintah Daerah yaitu: (1) Inovasi Tata Kelola Pemerintahan Daerah; (2) Inovasi Pelayanan Publik; (3) Inovasi Daerah lainnya sesuai dengan Urusan Pemerintahan yang menjadi kewenangan Daerah (Indonesia, 2015). Inovasi adalah proses kreatif dalam melakukan penemuan baru yang berbeda dan/atau modifikasi dari yang sudah ada (Anonim, 2014). Kriteria inovasi layanan publik yaitu: (1) Memiliki kebaruan; (2) Efektif; (3) Bermanfaat; (4) Berpotensi di tiru (replikasi); dan (5) Keberlanjutan (Anonim, 2021).

Sesuai amanah undang-undang dan peraturan-peraturan tersebut, Dinas Perpustakaan dan Kearsipan Kota Yogyakarta sebagai salah satu penyelenggara pemerintah bidang perpustakaan berupaya untuk meningkatkan kinerja dengan 
mengembangkan inovasi pelayanan dalam mencapai tujuan organisasi. Salah satunya adalah inovasi "SAPA RATU" (Sarana Peminjaman dan Pengembalian Buku Pustaka Langsung Tanpa Turun dari Kendaraan) istilah umum layanan drive-thru. Pemanfaatan teknologi informasi perpustakaan akan memberikan kemudahan bagi pemustaka dalam mengakses informasi di perpustakaan (Hartono, 2021: 27).

Pada saat pandemi, DPK Kota Yogyakarta membuka layanan dengan pembatasan pengunjung dan protokol kesehatan yang ketat. Hal tersebut dilakukan karena salah satu target kinerja organisasi adalah tingkat kunjungan pemustaka yang harus dipenuhi. Akan tetapi, seiring dengan kebijakan PPKM Darurat ketika layanan secara terbuka tidak diperbolehkan. Salah satu strategi untuk menaikkan jumlah pengunjung adalah optimalisasi inovasi layanan "SAPA RATU”. Jenis layanan layak dan relevan sebagai alternatif layanan di masa pandemi Covid-19.

Dalam penyelenggaraannya inovasi layanan "SAPA RATU" perlu memperhatikan kriteriasebuah inovasi yang telah ditetapkan oleh Kementerian terkait. Dari pengamatan sementara, layanan ini belum banyak dimanfaatkan oleh pemustaka. $\mathrm{Hal}$ tersebut tentu saja menarik untuk dikaji lebih lanjut untuk mengetahui bagaimana layanan tersebut, seberapa besar tingkat kemanfaatannya, dan kendala yang terjadi pada inovasi layanan tersebut. Dari hasil kajian ini diharapkan inovasi layanan "SAPA RATU” dapat dimanfaatkan lebih maksimal dan mampu mencapai tujuan organisasi yang diharapkan.

\section{B. Metode Penelitian}

Penelitian ini menggunakan desain penelitian studi kasus dengan metode penelitian deskriptif kualitatif. Penelitian deskriptif merupakan penelitian yang mengangkat fakta, keadaan, variable dan fenomena-fenomena yang terjadi saat sekarang dan menyajikan data apa adanya. Sedangkan studi kasus merupakan jenis penelitian deskriptif yang memusatkan perhatian pada kasus secara intensif dan mendetail, sehingga menghasilkan gambaran yang longitudinal yaitu hasil pengumpulan data dalam satu jangka waktu (Subana, 2005). Metode penelitian kualitatif adalah penelitian yang berlandaskan pada filsafat postpositivisme untuk meneliti obyek yang alamiah menempatkan peneliti sebagai instrument kunci, teknik pengumpulan data dilakukan secara triangulasi (gabungan), analisis data bersifat induktif, dan hasil penelitian yang lebih menekankan makna daripada generalisasi (Sugiyono, 2014).

Lokasi yang digunakan pada penelitian ini yaitu di DPK Kota Yogyakarta dan fenomena khusus yaitu tentang Inovasi "SAPA RATU”. Populasi adalah satuan analisis yang merupakan sasaran penelitian. Sedangkan sampel adalah himpunan bagian dari jumlah populasi (Gulo, 2010). Populasi dari penelitian ini adalah pustakawan dan pemustaka di DPK Kota Yogyakarta. Adapun sampel yang disebut sebagai informan dalam penelitian ini adalah beberapa pustakawan yang terlibat layanan "SAPA RATU" dan beberapa pemustaka di DPK Kota Yogyakarta. Teknik pengumpulan data menggunakan metode wawancara, pengamatan secara langsung, dokumentasi dan tinjauan literature. Sedangkan teknik analisis data yang digunakan adalah pengumpulan data, reduksi data, penyajian data, pembahasan dan penarikan kesimpulkan.

\section{Hasil dan Pembahasan}

DPK Kota Yogyakarta merupakan Organisasi Perangkat Daerah (OPD) di Pemerintah Kota Yogyakarta yang bertanggungjawab dalam bidang perpustakaan dan kearsipan. DPK Kota Yogyakarta memiliki slogan sebagai perpustakaan yang dinamis dan inovatif (The Dynamic and Inovatif Library). Hal tersebut ditandai dari banyaknya inovasi yang dimiliki salah satunya adalah layanan "SAPA RATU". Layanan "SAPA RATU" adalah layanan drive-thru untuk pemustaka yang meminjam dan mengembalikan buku pada loket di area luar ruang perpustakaan. Inovasi layanan di DPK Kota Yogyakarta ini diselenggarakan sebelum pandemi yaitu sejak Agustus 2019. Latar belakang diselenggarakan inovasi layanan "SAPA RATU” yaitu: (1) Mengurai kepadatan pada kegiatan sirkulasi layanan dalam; (2) Memfasilitasi 
pengunjung yang memiliki keterbatasan waktu; (3) Mempermudah layanan peminjaman dan pengembalian; (4) Mengurangi kepadatan parkir kendaraan; (5) Mengurangi penularan covid-19 di saat pandemi. Sedangkan dalam pelaksanannya layanan "SAPA RATU" didukung oleh 1 (satu) orang pustakawan sebagai petugas. Sedangkan sarana pendukung yaitu komputer, Alat Tulis Kantor (ATK), buku kunjungan "SAPA RATU”, barcode scanner, meja, kursi petugas, dan alat sterilisasi buku. Ilustrasi inovasi layanan "SAPA RATU” dapat dilihat pada Gambar 1.

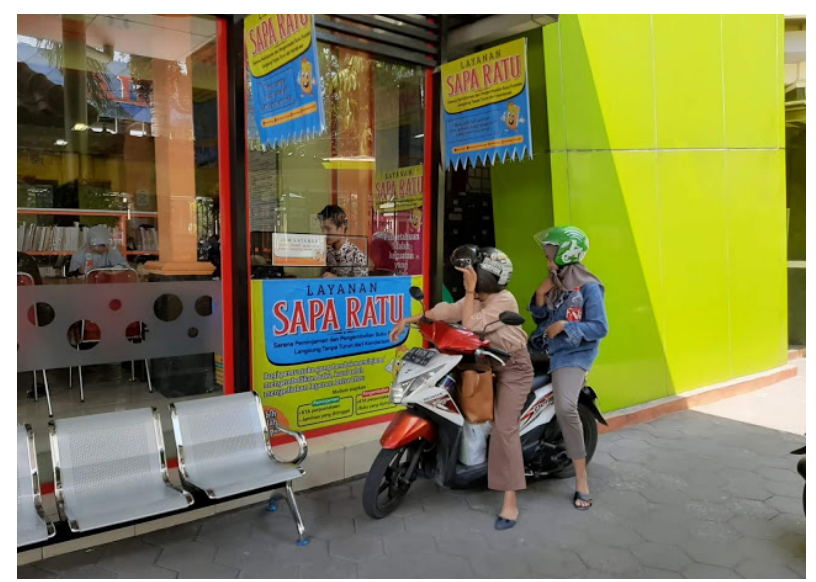

Gambar 1: Layanan “SAPA RATU” DPK Kota Yogyakarta. (Sumber: Dokumentasi DPK Kota Yogyakarta, 2021)
Inovasi layanan publik sebaiknya sesuai kriteria yang ditetapkan dalam Permen PANRB Nomor 7 Tahun 2021 pasal 6 menyebutkan tentang 5 (lima) kriteria yaitu kebaruan, efektif, bermanfaat, dapat di tiru (replikasi) dan berkelanjutan. Demikian pula pada inovasi layanan "SAPA RATU" berdasarkan berikut penjabaran berdasar kriteria yang ditetapkan:

1. Mengandung Unsur Kebaruan

Dalam bidang kuliner, jenis layanan drivethru ini sudah banyak dilakukan. Akan tetapi di bidang layanan perpustakaan, jenis layanan ini masih sedikit yang menerapkan. Selain DPK Kota Yogyakarta layanan yang serupa dengan layanan "SAPA RATU" ada di beberapa perpustakaan antara lain DPK Propinsi Jawa Timur. Inovasi drive-thru ini mulai diluncurkan pada Februari 2020 (Putra \& Niswah, 2021). Selanjutnya adalah Perpustakaan SMA Muhammadiyah 1 Yogyakarta yang menyelenggarakan layanan LANTATUR (Layanan Tanpa Turun) sejak Juli 2019 (Istiqomah \& Erdiyansyah, 2021).

\section{Efektif}

Inovasi layanan yang baik harus efektif. Efektif adalah pemanfaatan sumber daya,

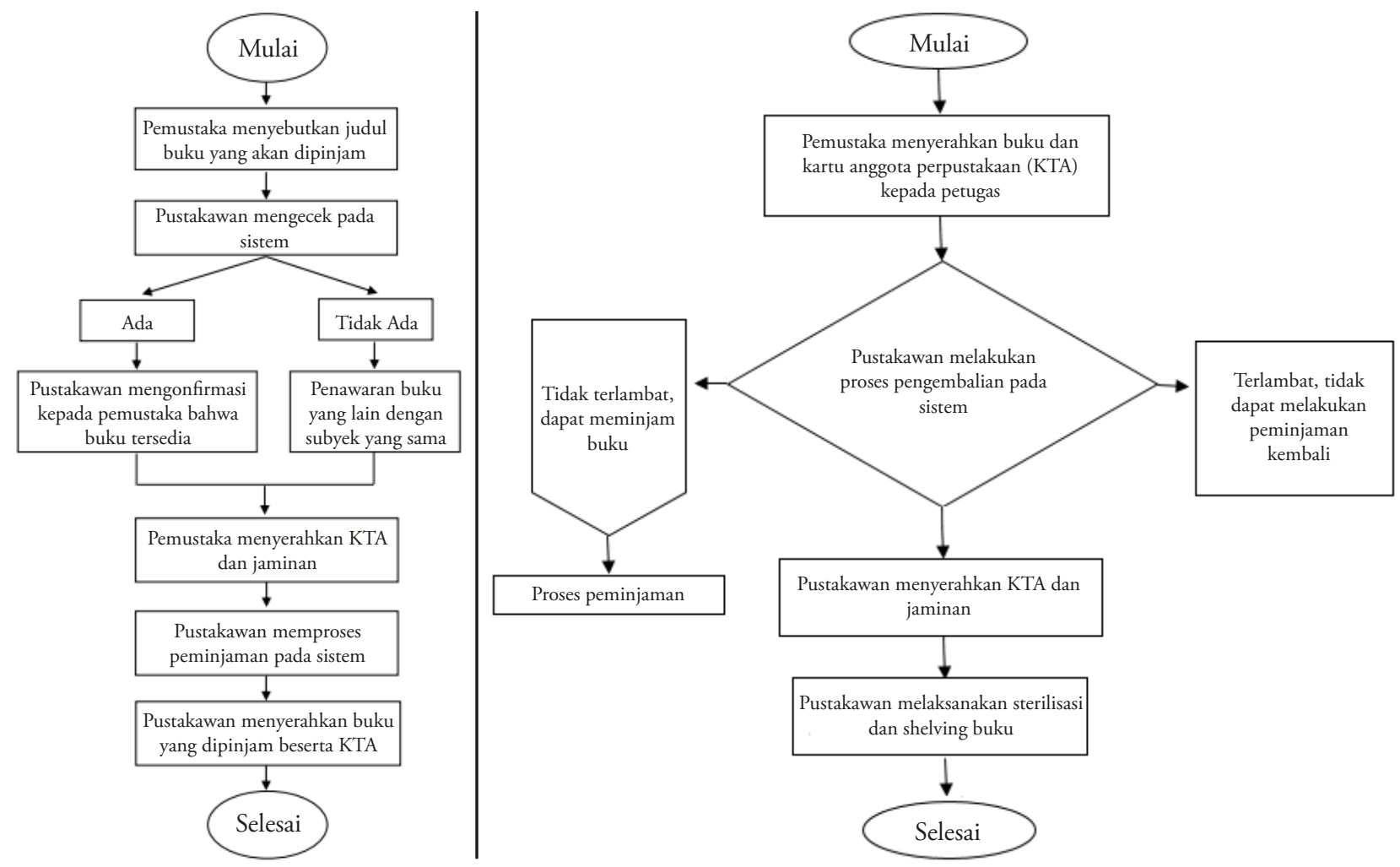

Gambar 2: Alur peminjaman dan pengembalian buku pada layanan "SAPA RATU”. (Sumber: Dokumentasi DPK Kota Yogyakarta, 2021) 
sarana dan prasarana dalam jumlah tertentu yang secara sadar ditetapkan sebelumnya untuk menghasilkan sejumlah pekerjaan tepat pada waktunya (Abdurahmat, 2003). Pengertian tersebut menjelaskan bahwa inovasi yang dilakukan harus memiliki hasil dengan memanfatkan sumber daya yang ada sesuai target yang ditetapkan. Target yang ditetapkan salah satunya berkaitan dengan alur layanan yang dapat dilihat pada Gambar 2.

Dari alur yang ada maka dapat dilihat bahwa pemustaka bisa langsung memanfaatkan layanan peminjaman dengan menyebutkan buku yang dipinjam, sedangkan layanan pengembalian dengan menyerahkan buku pada petugas. Pada peminjaman dan pengembalian pemustaka harus membawa kartu tanda anggota perpustakaan

Kepuasan pengguna adalah tujuan dari layanan. Untuk melihat tingkat kepuasan pemustaka terkait efektivitas waktu layanan, berikut hasil wawancara dengan Alfa (Wawancara tanggal 7 Agustus 2021) yang merupakan pengguna layanan "SAPA RATU" menyampaikan bahwa:

\section{"Layanan SAPA RATU cukup membantu saat pandemi sekarang ini tetapi pengunjung harus menunggu cukup lama untuk mengembalikan/meminjam buku karena antrian yang panjang".}

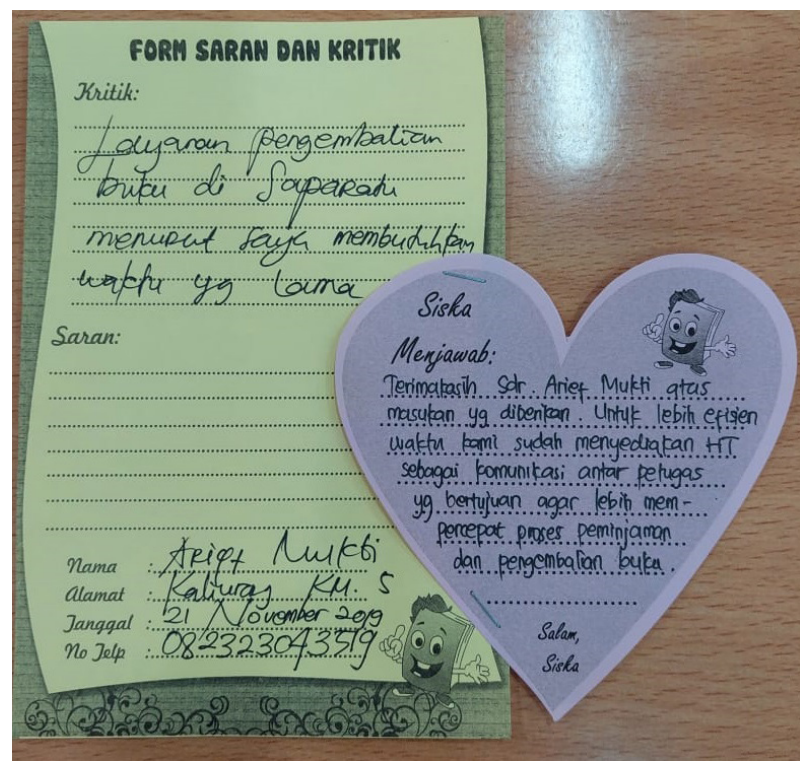

Gambar 3: Form "SISKA” tentang Layanan "SAPA RATU”. (Sumber: Dokumentasi DPK Kota Yogyakarta, 2021)
Pendapat lainnya berasal dari form "SISKA" atas nama Arief Mukti. "SISKA" adalah sarana interaksi antar pemustaka dengan pustakawan yang beriisi masukan, saran, dan pemesanan buku. Arief Mukti menyampaikan tentang layanan yang cukup lama ketika mengembalikan buku di "SAPA RATU". Contoh Form "SISKA" dapat dilihat pada Gambar 3.

Kendala waktu tidak lepas dari sumber daya yang ada pada pada layanan ini. Dari data yang diperoleh sebelumnya jumlah petugas di layanan "SAPA RATU" yang hanya 1 (satu) orang berpengaruh pada lama layanan yang diberikan. Terlebih jika layanan peminjaman harus mengambil buku atau mencarikan alternatif buku lainnya jika buku yang dicari tidak ada, tentu saja akan menambah jumlah waktu yang diperlukan untuk menyelesaikan layanan.

\section{Bermanfaat}

Inovasi Layanan harus memberikan manfaat pada tujuan inovasi yaitu untuk peningkatan kinerja perpustakaan salah satunya diukur dari jumlah kunjungan. Sedangkan bagi pemustaka, layanan ini bertujuan membantu pemustaka yang memiliki waktu sempit untuk berkunjung ke perpustakaan. Begitu juga inovasi "SAPA RATU" secara tidak langsung diharapkan mampu meningkatkan jumlah kunjungan di DPK Kota Yogyakarta. Jumlah pengguna "SAPA RATU” saat pandemi dari Maret s.d Juli 2021 dapat dilihat pada Grafik 2.

Dari data tersebut dapat dilihat bahwa pengguna layanan "SAPA RATU” tertinggi yaitu 338 orang pada April 2020, sedangkan Juli 2021 pengunjung paling sedikit dibandingkan pada bulan-bulan sebelumnya yaitu 51 orang.

Grafik 2: Pengguna layanan "SAPA RATU" pada bulan Maret-Juli 2021. (Sumber: Dokumentasi DPK Kota Yogyakarta, 2021)

Pengguna Layanan "SAPA RATU" saat Pandemi pada Maret 2020-Juli 2021

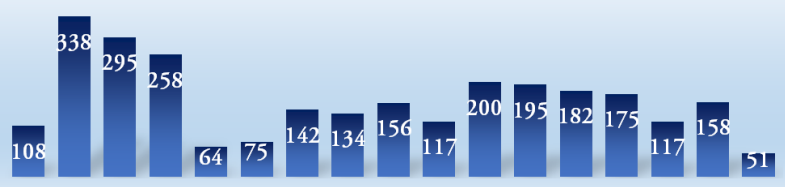

Mar Apr Mei Juni Juli Agu Sep Okt Nov Des Jan Feb Mar Apr Mei Juni Juli $\begin{array}{lllllllllllllllll}20 & 20 & 20 & 20 & 20 & 20 & 20 & 20 & 20 & 20 & 21 & 21 & 21 & 21 & 21 & 21 & 21\end{array}$ 
Telah disampaikan sebelumnya bahwa di awal pandemi selain layanan "SAPA RATU”, DPK Kota Yogyakarta juga membuka layanan tatap muka secara terbuka (reguler) dengan pembatasan jumlah pemustaka. Kecuali bulan Juli 2021 mulai diberlakukan PPKM Darurat layanan regular di tutup. Jumlah pemustaka yang menggunakan layanan"SAPA RATU" dan pemustaka yang menggunakan layanan regular dapat dilihat pada Grafik 3.

Dari Grafik 3 tersebut dapat dilihat terjadi penurunan pengunjung yang signifikan ditahun 2021. Walau tahun 2021 baru berjalan 6 (enam) bulan dengan jumlah yang tertera patut menjadi perhatian oleh DPK Kota Yogyakarta. Sedangkan pengguna layanan "SAPA RATU" mengalami peningkatan 6 (enam) bulan terakhir. Hal tersebut tidak lepas dari situasi dan kasus pandemi Covid-19 yang tinggi di awal tahun 2021 hingga saat ini. Selain itu dari wawancara yang dilaksanakan dengan Indah Gemala (Wawancara tanggal 7 Agustus 2021) menyampaikan:

"Saya belum tahu tentang inovasi Sapa Ratu dan belum pernah menggunakan, tetapi sepertinya inovasi tersebut membantu pemustaka khusunya di masa pandemi."

Salah satu upaya yang dilakukan oleh DPK Kota Yogyakarta untuk mengatasi kendala yang ada adalah melaksanakan publikasi layanan. Salah satu publikasi layanan "SAPA RATU” melalui laman sosial media DPK Kota Yogyakarta dapat dilihat pada Gambar 4.

Grafik 3: Jumlah pemustaka layanan regular dan layanan "SAPA RATU". (Sumber: Dokumentasi DPK Kota Yogyakarta, 2021)

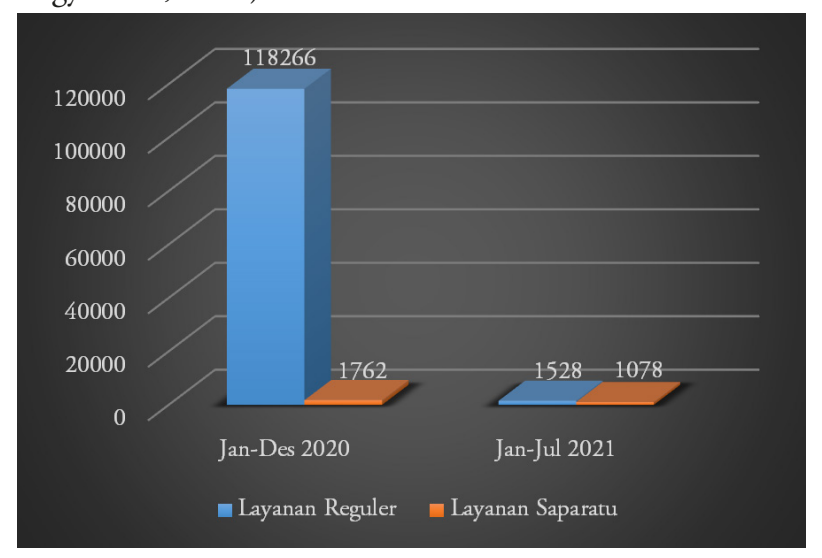

Publikasi melalui media online yang dilakukan oleh DPK Kota Yogyakarta sudah tepat. Hal tersebut diperkuat oleh penelitian sebelumnya, optimalisasi layanan secara online solusi layanan di saat pendemi Covid-19 (Mustar, 2020). Pendapat yang lain Aulia menyatakan bahwa, dengan menggunakan media sosial pemustaka akan tahu buku-buku terbaru, tahun tentang informasi perpustakaan, perpustakaan akan lebih dikenal, memiliki jaringan yang luas, dengan cepat dan fleksibel (Aulia, 2020).

4. Dapat Ditiru (Replikasi)

Inovasi yang baik adalah inovasi yang mudah ditiru oleh pihak lain. Begitu halnya dengan layanan 'SAPA RATU" merupakan inovasi mudah untuk ditiru karena cukup sederhana termasuk sarana prasarananya. Dapat mengoptimalkan sarana yang sudah ada di masing-masing perpustakaan. Bukti inovasi layanan "SAPA RATU" dapat ditiru yaitu adanya beberapa perpustakaan lain yang juga melaksanakan layanan serupa baik di perpustakaan perguruan tinggi, perpustakaan

puskotjogja

Perpustakaan Kota Jogja

$\vdots$

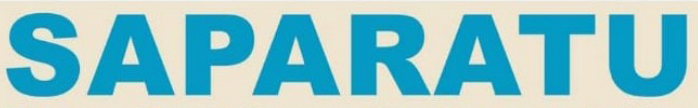

Sarana Peminjaman dan Pengembalian Buku Tanpa Turun dari Kendaraan

Jam Layanan

Senin - Jumat | 09.00 - 13.00 WIB

Sabtu \& Minggu TUTUP

Syarat Peminjaman

Membawa KTA dan Kartu Identitas yang masih berlaku

Untuk Pencarian Buku

(-) admperpus.jogjakota.go.id/inlislite3/opac/

Untuk Pemesanan

Kotabaru (? 081390951274

Pevita (C) 081226839100

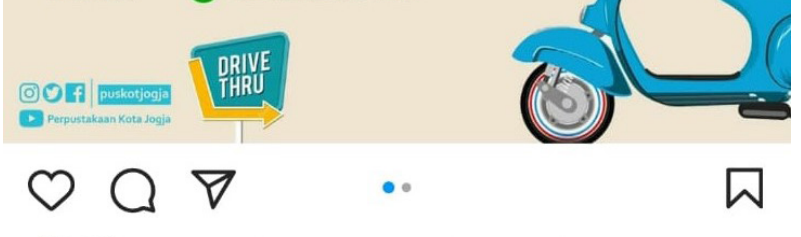

\$2 Disukai oleh shrmnsyh dan 49 lainnya

puskotjogja Apa kabar sobat? Semoga sehat-sehat semuanya yaa..... lainnya

Gambar 4: Publikasi "SAPA RATU” pada instagram DPK Kota Yogyakarta. (Sumber: Dokumentasi DPK Kota Yogyakarta, 2021) 
umum maupun perpustakaan sekolah seperti yang telah disampaikan sebelumnya yaitu DPK Provinsi Jawa Timur dan Perpustakaan SMA Muhammadiyah 1 Yogyakarta.

5. Berkelanjutan

Inovasi layanan yang baik adalah berkelanjutan artinya tidak hanya berlaku dalam jangka pendek. Dari perkembangan dan upaya yang dilakukan oleh DPK Kota Yogyakarta layanan ini memiliki peluang untuk terus dikembangkan dan diperbaiki. Tujuannya adalah supaya inovasi "SAPA RATU” berjalan lebih optimal. Bersadarkan wawancara yang dilakukan dengan Dwi Ferimawati (Wawancara tanggal 5 Agustus 2021) pustakawan DPK Kota Yogyakarta menyampaikan:

"Evaluasi layanan "SAPA RATU" dilakukan secara rutin dalam rapat "SISKA". Dalam rapat itu semua masukan terhadap layanan dibahas dan dicarikan jalan keluarnya".

Dari pengamatan yang dilakukan pimpinan di DPK Kota Yogyakarta memberikan dukungan penuh untuk mengoptimalkan layanan yang dapat diselenggarakan di masa pandemi salah satunya adalah layanan "SAPA RATU".

Dari data-data dan fakta yang ditemukan dan telah disampaikan di atas, terdapat beberapa catatan dalam penyelenggaraan inovasi layanan "SAPA RATU" sebagai salah satu strategi dalam layanan saat pandemi yaitu:

a. Inovasi layanan harus memperhatikan 5 (lima) kriteria yang harus dipenuhi dalam penyelenggaraan layanan publik yaitu kebaruan, efektif, bermanfaat, dapat ditiru dan berkelanjutan. Hal tersebut sangat penting agar inovasi yang dilakukan dapat meningkatkan kinerja organisasi sekaligus memberikan kemanfaatan bagi masyarakat.

b. Berkaitan dengan efektivitas ada beberapa yang dapat dijadikan catatan oleh penyelenggara layanan agar mencari solusi dari kendala yang ada yaitu waktu layanan yang cukup lama terlebih jika ada beberapa pemustaka yang bersamaan. Perlunya sistem yang lebih efektif tempat yang lebih strategis supaya pengguna layanan lebih nyaman ketika menunggu antrian. c. Perlunya publikasi layanan dan publikasi buku baru yang lebih sering. Dengan demikian layanan "SAPA RATU” akan dikenal oleh banyak orang dan akhirnya tertarik untuk memanfaatkan layanan.

d. Perlunya sistem yang tepat untuk peminjaman buku agar tidak membutuhkan waktu yang lama yaitu dengan cara pesan minimal 1 (satu) hari sebelum kedatangan melalui saran yang telah disediakan.

\section{Kesimpulan dan Saran}

Inovasi saat pendemi adalah strategi organisasi agar dapat menjalankan kinerja berdasarkan tugas dan fungsinya ditengah keterbatasan. Inovasi yang diselenggarakan harus memenuhi kriteria dalam inovasi layanan publik. Salah satu strategi layanan saat pandemi adalah "SAPA RATU" yang diselenggarakan oleh Dinas dan Perpustakaan Kota Yogyakarta. Layanan ini sebuah inovasi untuk mengoptimalkan layanan di masa pandemi Covid-19 dengan sistem drive-thru. Inovasi ini mudah ditiru oleh perpustakaan lain dengan memanfatkan sumber daya yang ada.

Dalam penyelenggaraannya layanan "SAPA RATU” memiliki kekurangan. Namun hal tersebut dijadikan evaluasi untuk menjadi lebih baik. Hal tersebut dilakukan karena kepuasan pengguna adalah tujuan utama dari layanan. Selain itu terdapat hal-hal yang perlu perhatikan yaitu pentingnya komitmen dari pimpinan, mengetahui kebutuhan pengguna, penguatan promosi layanan, kompetensi pustakawan yang handal, serta sistem yang tepat dan efektif. Dengan inovasi layanan yang optimal diharapkan mampu memberikan kemanfaatan kepada masyarakat maupun organisasi.

\section{Kepustakaan}

Abdurahmat. (2003). Pengertian Efektivitas. Rineka Cipta.

Anonim. (2014). Peraturan Menteri Pemberdayaan Aparatur Negara dan Reformasi Birokrasi RI Nomor 30 Tahun 2014 tentang Pedoman Inovasi Pelayanan Publik.

Anonim. (2021). Peraturan Menteri Pendayagunaan 
Aparatur Negara dan Reformasi Birokrasi Nomor 7 Tahun 2021 tentang Kompetisi Inovasi Pelayanan Publik di Lingkungan Kementerian/ Lembaga, Pemerintah Daerah, Badan Usaha Milik Negara, dan Badan Usaha Milik Daerah.

Aulia, F. (2020). Promosi Jasa Layanan Perpustakaan pada Generasi Milenial di Masa Pandemi. Repository.Uinsu.ac.id, 10.

Gulo, W. (2010). Metodologi Penelitian. Gramedia. Hartono, A. (2021). Pemustaka di Perpustakaan Program Pascasarjana ISI Yogyakarta Setelah Penerapan Protokol Kesehatan Covid-19. ABDI PUSTAKA: Jurnal Perpustakaan dan Kearsipan, 1(1), 25-31. https://doi. org/10.24821/jap.v1i1.5912

Indonesia. (2015). Undang-Undang RI Nomor 9 Tahun 2015 Tentang Pemerintah Daerah.

Istiqomah, Z., \& Erdiyansyah, M. (2021). Lantatur sebagai Alternatif Layanan Perpustakaan Sekolah di Masa Pandemi Covid-19. 1(1), 29-41. https://doi.org/10.21580/daluang. v1i1.2021.7987

Mustar, M. (2020). Layanan Perpustakaan di
Tengah Pandemi Covid-19. Buku KMP 9, Pustakawan, Perpustakaan, Dan Kebencanaan, 9, 193-213.

Pasalong, H. (2007). Teori Administrasi Publik. Alfabeta.

Pusparisa, Y. (2021). Peringkat Tiga di Dunia, Kasus Covid-19 Indonesia Turun 5 Persen dalam Sepekan.

Putra, A. W., \& Niswah, F. (2021). Inovasi Layanan Drive-Thru Perpustakaan Untuk Meningkatkan Budaya Literasi (Studi Di Dinas Perpustakaan Dan Kearsipan Provinsi Jawa Timur). Publika, 25-38. https://doi. org/10.26740/publika.v9n2.p25-38

Samiyati, S., Suratmi, I., \& Santoso, J. (2021). Pemanfaatan Layanan Perpustakaan dan Prestasi Akademis Mahasiswa. ABDI PUSTAKA: Jurnal Perpustakaan dan Kearsipan, 1(1), 32-38. https://doi.org/10.24821/jap. v1i1.5915

Subana, M. (2005). Dasar-Dasar Penelitian Ilmiah. Pustaka Setia.

Sugiyono. (2014). Metode Penelitian Kuantitatif Kualitatif dan R\&D. Alfabeta. 